\title{
Influence of cracking clays on satellite estimated and model simulated soil moisture
}

\author{
Y. Y. Liu 1,4, , J. P. Evans' ${ }^{2}$, M. F. McCabe ${ }^{1}$, R. A. M. de Jeu ${ }^{3}$, A. I. J. M. van Dijk ${ }^{4}$, and H. Su \\ ${ }^{1}$ School of Civil and Environmental Engineering, University of New South Wales, Sydney, Australia \\ ${ }^{2}$ Climate Change Research Centre, University of New South Wales, Sydney, Australia \\ ${ }^{3}$ Department of Hydrology and Geo-Environmental Sciences, Faculty of Earth and Life Sciences, Vrije Universiteit \\ Amsterdam, Amsterdam, The Netherlands \\ ${ }^{4}$ CSIRO Land and Water, Black Mountain Laboratories, Canberra, Australia \\ ${ }^{5}$ Center for Research on Environment and Water, Calverton, MD, USA \\ *now at: School of Civil and Environmental Engineering, University of New South Wales, Sydney, Australia
}

Received: 19 January 2010 - Published in Hydrol. Earth Syst. Sci. Discuss.: 4 February 2010

Revised: 28 May 2010 - Accepted: 7 June 2010 - Published: 18 June 2010

\begin{abstract}
Vertisols are clay soils that are common in the monsoonal and dry warm regions of the world. One of the characteristics of these soil types is to form deep cracks during periods of extended dry, resulting in significant variation of the soil and hydrologic properties. Understanding the influence of these varying soil properties on the hydrological behavior of the system is of considerable interest, particularly in the retrieval or simulation of soil moisture. In this study we compare surface soil moisture $\left(\theta\right.$ in $\left.\mathrm{m}^{3} \mathrm{~m}^{-3}\right)$ retrievals from AMSR-E using the VUA-NASA (Vrije Universiteit Amsterdam in collaboration with NASA) algorithm with simulations from the Community Land Model (CLM) over vertisol regions of mainland Australia. For the threeyear period examined here (2003-2005), both products display reasonable agreement during wet periods. During dry periods however, AMSR-E retrieved near surface soil moisture falls below values for surrounding non-clay soils, while CLM simulations are higher. CLM $\theta$ are also higher than AMSR-E and their difference keeps increasing throughout these dry periods. To identify the possible causes for these discrepancies, the impacts of land use, topography, soil properties and surface temperature used in the AMSR-E algorithm, together with vegetation density and rainfall patterns, were investigated. However these do not explain the observed $\theta$ responses. Qualitative analysis of the retrieval model suggests that the most likely reason for the
\end{abstract}

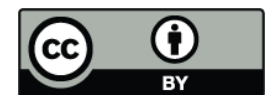

Correspondence to: Y. Y. Liu (yi.y.liu@csiro.au) low AMSR-E $\theta$ is the increase in soil porosity and surface roughness resulting from cracking of the soil. To quantitatively identify the role of each factor, more in situ measurements of soil properties that can represent different stages of cracking need to be collected. CLM does not simulate the behavior of cracking soils, including the additional loss of moisture from the soil continuum during drying and the infiltration into cracks during rainfall events, which results in overestimated $\theta$ when cracks are present. The hydrological influence of soil physical changes are expected to propagate through the modeled system, such that modeled infiltration, evaporation, surface temperature, surface runoff and groundwater recharge should be interpreted with caution over these soil types when cracks might be present. Introducing temporally dynamic roughness and soil porosity into retrieval algorithms and adding a "cracking clay" module into models are expected to improve the representation of vertisol hydrology.

\section{Introduction}

Soil moisture is a key variable in the water and energy cycles and its accurate representation and measurement is required for estimation and prediction of infiltration, evaporation, runoff and latent, sensible and ground heat fluxes. Soil moisture over large scales can be derived from remote sensing observations (e.g., Owe et al., 2008; Gao et al., 2006; Wen et al., 2003; Wagner et al., 1999) or model simulations (e.g., Evans and McCabe, 2010; Rodell et al., 2004). Comparing remotely sensed soil moisture with other independent

Published by Copernicus Publications on behalf of the European Geosciences Union. 


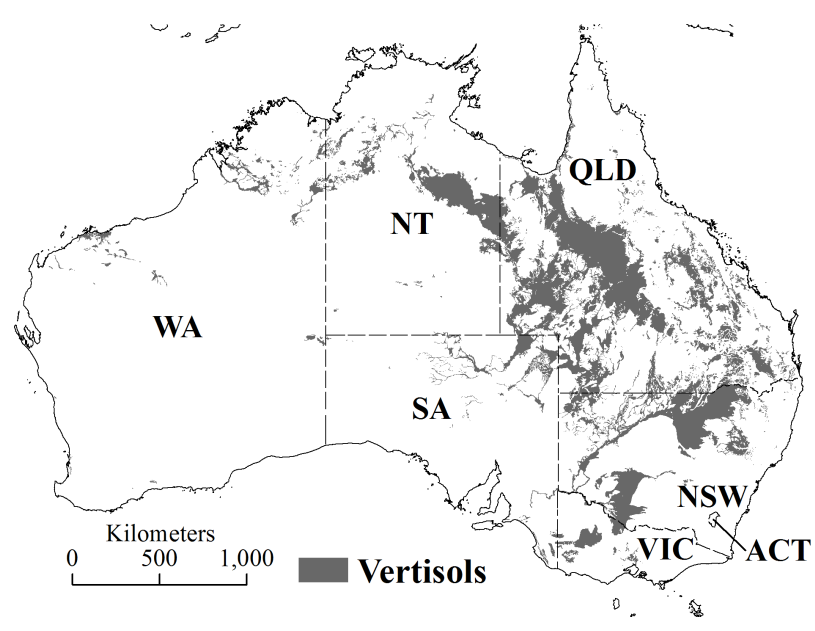

Fig. 1. Spatial distribution of vertisols over mainland Australia (based on Isbell, 2002).

soil moisture products such as ground observations, models or other remote sensing techniques (McCabe et al., 2008; Scipal et al., 2008; Draper et al., 2009) allows for better understanding of soil moisture estimates derived by different approaches (Wagner et al., 2003; McCabe et al., 2005a). Several such studies have been conducted and generally show reasonably good correspondence between remotely sensed and modeled soil moisture (Choi et al., 2008; Rüdiger et al., 2009; Santanello Jr. et al., 2007; Vischel et al., 2008).

However, these comparison studies pay little attention to large scale vertisol regions. Vertisols cover more than 3 million $\mathrm{km}^{2}$ globally, with major areas including eastern Australia, particularly Queensland with 0.5 million $\mathrm{km}^{2}$ and New South Wales (see Fig. 1), as well as the Deccan Plateau of India, eastern Africa, South America and parts of eastern China. Due to the desirable agricultural and hydraulic characteristics of clay soils, they are disproportionally important for cropping and irrigation, which makes accurate representation of the behavior of the soil moisture response important in characterizing their water and energy balances. Key features of these soils include swelling during wetting periods and shrinking during drying periods, with the potential for cracks to develop under extended dry conditions. The pore volume of vertisol soils varies with moisture condition, increasing the difficulty in accurately estimating moisture content (Cornelis et al., 2006).

Given the relative importance of these soil regions in agricultural production, the accurate representation of soil moisture response is of considerable interest. In the absence of detailed in situ measurements, remote sensing and land surface modeling approaches offer the only means to obtain estimates of the soil moisture state. Identifying whether these approaches are capable of reflecting the expected responses of vertisol soils is required. In order to assess the reproduction of soil moisture response in clay soils, we compare the near surface soil moisture content $\left(\theta\right.$ in $\left.\mathrm{m}^{3} \mathrm{~m}^{-3}\right)$ derived from the Advanced Microwave Scanning Radiometer (AMSR-E) with the upper layer moisture content from the Community Land Model (CLM) across mainland Australia, focusing on the vertisol regions identified in Fig. 1.

Monthly averages of soil moisture from AMSR-E and CLM for January and October 2004 are shown in Fig. 2. January is the monsoon season for northern Australia and the dry season for the south, while October is the wet season over southern Australia (particular southeast and southwest) and dry season over the north. The expected soil moisture responses to these large scale precipitation trends are clearly reflected in both satellite based retrievals and in land surface model output. In the vertisol regions of north Australia, the soil moisture is clearly higher than the surrounding non-clay soils during the wet season (see Fig. 2a and b). For the land surface model data, this trend continues into the dry season (Fig. 2d). For AMSR-E retrievals however, the clay soils illustrate a lower moisture state relative to surrounding areas (Fig. 2c). Under similar meteorological conditions, the soil moisture content of clay soils would not be expected to be lower than non-clay soils, since the smaller clay particles are able to retain more water molecules. Temporally, the divergence between the land surface model and AMSR-E starts at the end of the rainy season, keeps increasing through the dry season and peaks at the beginning of the next rainy season (Fig. 3).

Explaining these differing responses is the key motivation of the current paper. Explicitly, we seek answers to the following questions. First, what causes the low values of AMSR-E $\theta$ over vertisols during dry periods? Second, what causes the increasing difference between AMSR-E and CLM $\theta$ during dry and early rainy seasons over vertisols? Also, if CLM does not reasonably represent soil moisture temporal dynamics on vertisols, what are the potential impacts on linked hydrological components?

In identifying the possible reasons for observed variations, a number of contributing factors will be examined, including:

- the influences of topographic conditions and land use;

- the impacts of soil properties (by running the retrieval algorithm using uniform soil properties);

- the effects of vegetation density on the accuracy of AMSR-E $\theta$ retrievals;

- the temporal dynamics of other hydrological influences such as rainfall; and

- the hydrological influences of cracks developed during dry periods.

All of these have the potential to influence both the simulated soil moisture from CLM and the retrieval algorithm used to derive near soil moisture from AMSR-E. The following sections outline the data sources and the methodology 
(a) AMSR-E (January 2004)

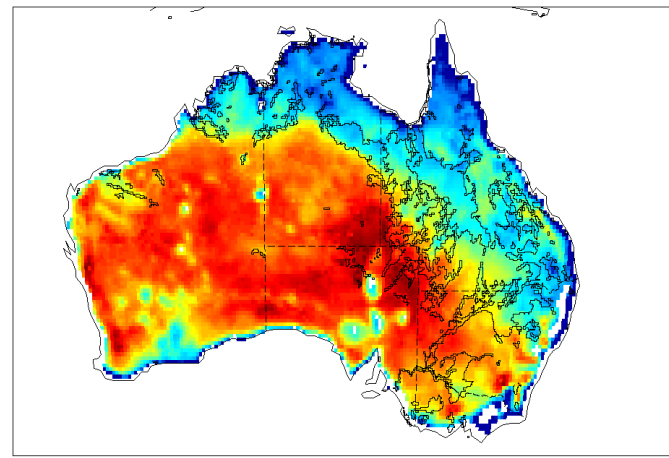

(c) AMSR-E (October 2004)

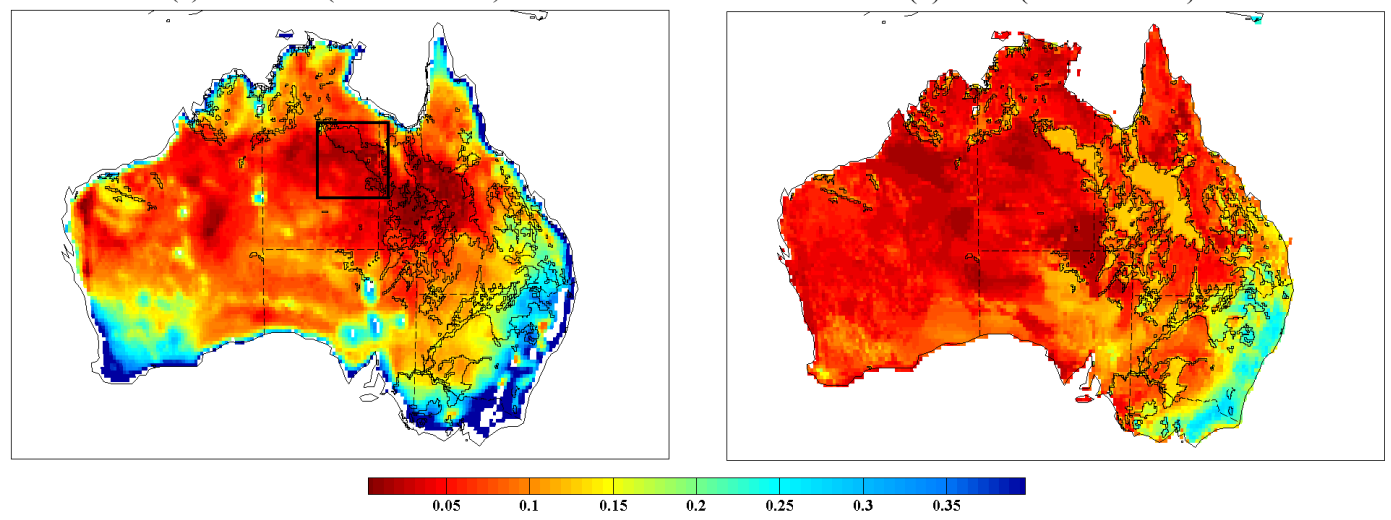

(b) CLM (January 2004)

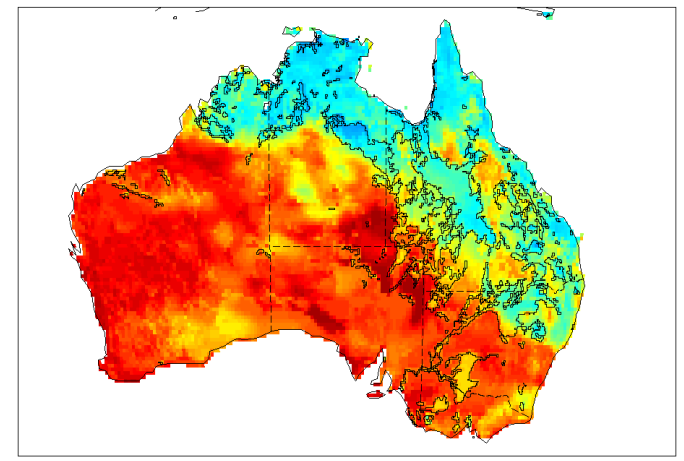

(d) CLM (October 2004)

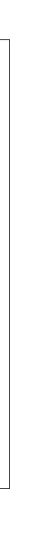

Fig. 2. Monthly averages of AMSR-E retrieved and CLM simulated $\theta\left(\mathrm{m}^{3} \mathrm{~m}^{-3}\right)$ for January and October 2004, describing the moisture condition during the wet and dry season for northern Australia, respectively. The black lines indicate the extent of vertisols. Average daily AMSR-E $\theta$ of vertisol areas within the black square (panel c) is plotted in Fig. 3.

employed to discriminate the possible reasons for the differing soil moisture responses observed between these two estimation techniques, and identify where improvements in descriptions of the soil physical processes might be required to improve estimation over vertisol soil types.

\section{Data sources}

The following sections briefly outline the sources and types of information used in this analysis.

\subsection{AMSR-E soil moisture}

The AMSR-E sensor onboard NASA's Aqua satellite has been providing passive microwave measurements at $6.9 \mathrm{GHz}$ (C-band) and five higher frequencies (including $36.5 \mathrm{GHz}$ Ka-band) since May 2002, with daily ascending (13:30 equatorial local crossing time) and descending (01:30 equatorial local crossing time) overpasses.

There are several algorithms to retrieve soil moisture using AMSR-E observed brightness temperatures. Draper et al. (2009) illustrated that the soil moisture retrievals by an algorithm developed by Vrije Universiteit Amsterdam, in collaboration with NASA (hereafter VUA-NASA) had better correspondence to in situ data over south-eastern Australia than other retrievals. In addition, no apparent radio frequency interference on AMSR-E C-band brightness temperature was observed over Australia (Njoku et al., 2005), making this a useful test-bed to analyze retrievals from this band. Therefore, the VUA-NASA product is applied in this study.

The VUA-NASA algorithm uses the Land Parameter Retrieval Model (LPRM), requiring horizontal $(\mathrm{H})$ and vertical (V) polarization C-band and V polarization Ka-band brightness temperatures $\left(T_{\mathrm{b}}\right)$ (Owe et al., 2008). Soil surface temperature is estimated from Ka-band $T_{\mathrm{b}}$ (Holmes et al., 2009). The vegetation optical depth ( $\tau$, dimensionless) and soilwater mixture dielectric constant are derived simultaneously. The soil moisture is solved from the dielectric constant using the Wang-Schmugge model (Wang and Schmugge, 1980). Several assumptions are made in the LPRM, including: a constant single scattering albedo, canopy surface temperature equal to soil surface temperature, equality of vegetation parameters for both $\mathrm{H}$ and $\mathrm{V}$ polarizations, and minimal effect of surface roughness (De Jeu, 2003).

Here we use $\theta$ retrievals acquired by descending passes as the minimal temperature gradients at midnight are more favorable for the retrievals (De Jeu, 2003). Soil moisture retrievals from C-band were re-sampled to $0.25^{\circ}$ (about $25 \mathrm{~km}$ ) 
(a) Time series of CLM/AMSR-E soil moisture

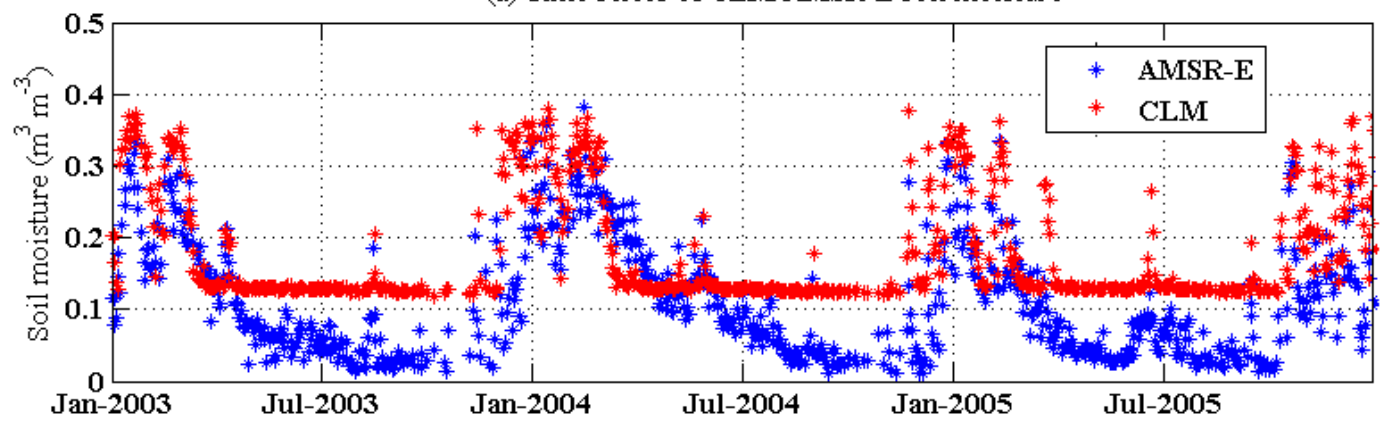

(b) Difference between CLM and AMSR-E

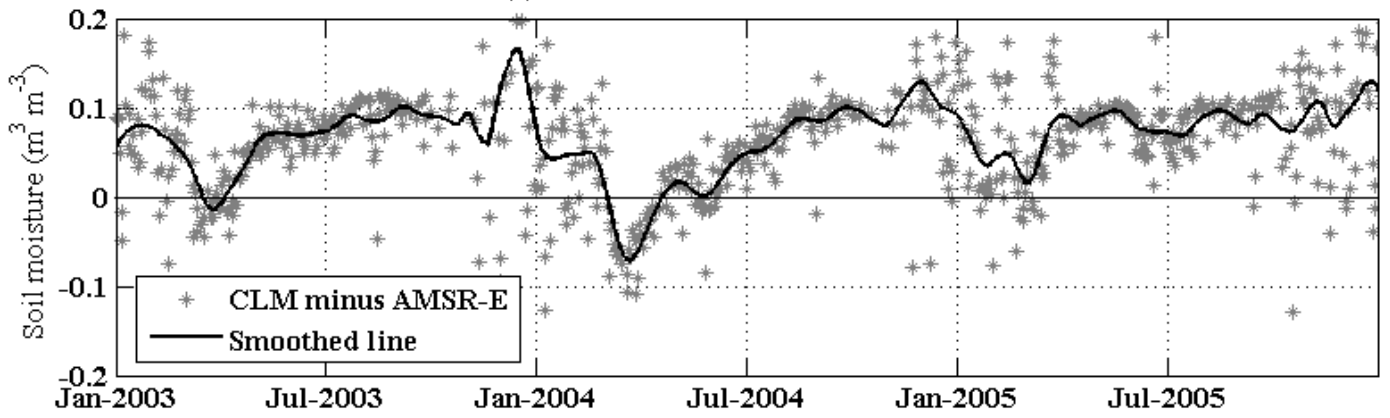

Fig. 3. (a) Average daily CLM simulated and AMSR-E retrieved $\theta$ for the vertisol soils within the square shown in Fig. 2c from 1 January 2003 through 31 December 2005. (b) Difference between daily CLM and AMSR-E $\theta$. The smooth line was derived by taking a 30-day moving average.

resolution over mainland Australia. The $\mathrm{C}$-band $\theta$ represents the top few centimeters of soil. For example, the penetration depth of AMSR-E C-band is about $1 \mathrm{~cm}$ for $\theta$ of $0.2 \mathrm{~m}^{3} \mathrm{~m}^{-3}$, and $2 \mathrm{~cm}$ for $\theta$ of $0.1 \mathrm{~m}^{3} \mathrm{~m}^{-3}$ (Kuria et al., 2007).

\subsection{Land surface model soil moisture}

The CLM is a publicly available distributed land surface model that combines components from the Common Land Model and the National Center for Atmospheric Research Land Surface Model (NCAR-LSM) (Oleson et al., 2004; Dai et al., 2003).

In CLM, the vertical profiles of sand and clay are taken into account by using a 10-layered soil component (Bonan et al., 2002). In this study, we only use the top layer soil moisture (about $1.8 \mathrm{~cm}$ ), giving a depth comparable with the AMSR-E soil moisture. Soil moisture dynamics of the top layer are governed by infiltration, surface and sub-surface runoff, gradient diffusion, gravity and evapotranspiration, with soil hydraulic properties defined as functions of sand and clay percentage ( $p_{\text {sand }}$ and $\left.p_{\text {clay }}\right)$. Equations describing the soil properties are given below; additional details about CLM can be obtained from Oleson et al. (2004).

$\theta_{\text {sat }}=0.489-0.00126\left(p_{\text {sand }}\right)$

$\Psi_{\text {sat }}=-10.0 \times 10^{1.88-0.0131\left(p_{\text {sand }}\right)}$
$B=2.91+0.159\left(p_{\text {clay }}\right)$

$\Psi=\Psi_{\text {sat }}\left(\theta / \theta_{\text {sat }}\right)^{-B}$

where $\theta_{\text {sat }}$ is the saturated soil moisture $\left(\mathrm{m}^{3} \mathrm{~m}^{-3}\right), \Psi_{\text {sat }}$ is the saturated soil matric potential $(\mathrm{mm}), \theta$ is soil moisture $\left(\mathrm{m}^{3} \mathrm{~m}^{-3}\right)$ and $\Psi$ is soil matric potential (mm) (Oleson et al., 2004).

For this study, CLM was run at a 3-hourly time step and the outputs were re-sampled to $0.25^{\circ}$ spatial resolution. To correspond with the time of the AMSR-E descending overpass, CLM soil moisture values at 01:00 a.m. LT were used for comparison. The unit of CLM soil moisture is $\mathrm{kg} \mathrm{m}^{-2}$. Given that the soil layer depth is $1.8 \mathrm{~cm}$, CLM soil moisture $\left(\mathrm{kg} \mathrm{m}^{-2}\right)$ was converted to $\theta\left(\mathrm{m}^{3} \mathrm{~m}^{-3}\right)$ for direct comparison with AMSR-E retrievals.

The LPRM and CLM model both use the same soil property dataset (http://ldas.gsfc.nasa.gov/gldas/GLDASsoils. php). The dataset is based on the Food and Agriculture Organization (FAO) Soil Map of the World, which is linked to a global database of over 1300 soil samples. The data was spatially re-sampled to $0.25^{\circ}$ resolution for use in LPRM and CLM.

\subsection{Vegetation information}

The Normalized Difference Vegetation Index (NDVI) product, derived from the Advanced Very High Resolution 
Radiometer (AVHRR) instruments on-board the National Oceanic and Atmospheric Administration (NOAA) platforms, is provided in the Global Inventory Monitoring and Modeling Studies (GIMMS) (see http://glcf.umiacs.umd. edu/data/gimms/) dataset (Tucker et al., 2005). GIMMS was used in this study to examine vegetation density, together with the monthly AMSR-E vegetation optical depth $(\tau)$ that is simultaneously retrieved with AMSR-E $\theta$. Both of these variables are indicators of vegetation density, although they have different physical interpretations. In general, NDVI represents the greenness of vegetation, and vegetation optical depth is largely a function of vegetation water content and total biomass (De Jeu, 2003). Higher retrieval accuracy of soil moisture is expected with lower vegetation density (Jackson and Schmugge 1995; Njoku and Entekhabi 1996).

\subsection{Precipitation data}

The dynamics in $\theta$ are expected to be well correlated to rainfall (McCabe et al., 2005b). Gridded rainfall data for mainland Australia were included in the analysis for comparison with soil moisture patterns. The data were interpolated from point observations by the Queensland Department of Natural Resources and Mines (http://www.longpaddock.qld.gov. $\mathrm{au} / \mathrm{silo} /$ ). The original daily $0.05^{\circ}$ resolution gridded data was re-sampled to $0.25^{\circ}$ resolution to allow direct comparison.

\subsection{Topographic data}

The GEODATA 9s digital elevation model (DEM-9S) version 3 product was used in this analysis to establish the topographic conditions (see http://www.ga.gov.au). This product, jointly developed by the Australian National University and Geoscience Australia, provides a grid of ground level elevation covering the whole Australia, with a spacing of $9 \mathrm{~s}$ in longitude and latitude (approximately $250 \mathrm{~m}$ ).

\section{Results and discussions}

\subsection{Effects of surface and atmospheric variables on AMSR-E}

This section focuses on the effects of topography, land use, vegetation density, and precipitation pattern on the AMSR-E soil moisture retrievals over the vertisols.

The large scale vertisol region spanning from NT to central QLD (Fig. 1), which exhibits low AMSR-E $\theta$ during dry periods (Fig. 2c), is referred to as the Mitchell Grass Downs. The region is dominated by Mitchell grasses, lacking in native trees (attributed to the deep cracking behavior of the clay soils) and used predominantly for cattle grazing (ANRA, 2001). Large scale land management practices such as tillage that may potentially impact surface roughness and/or vegetation cover are unlikely to occur, thus the low AMSR-E $\theta$

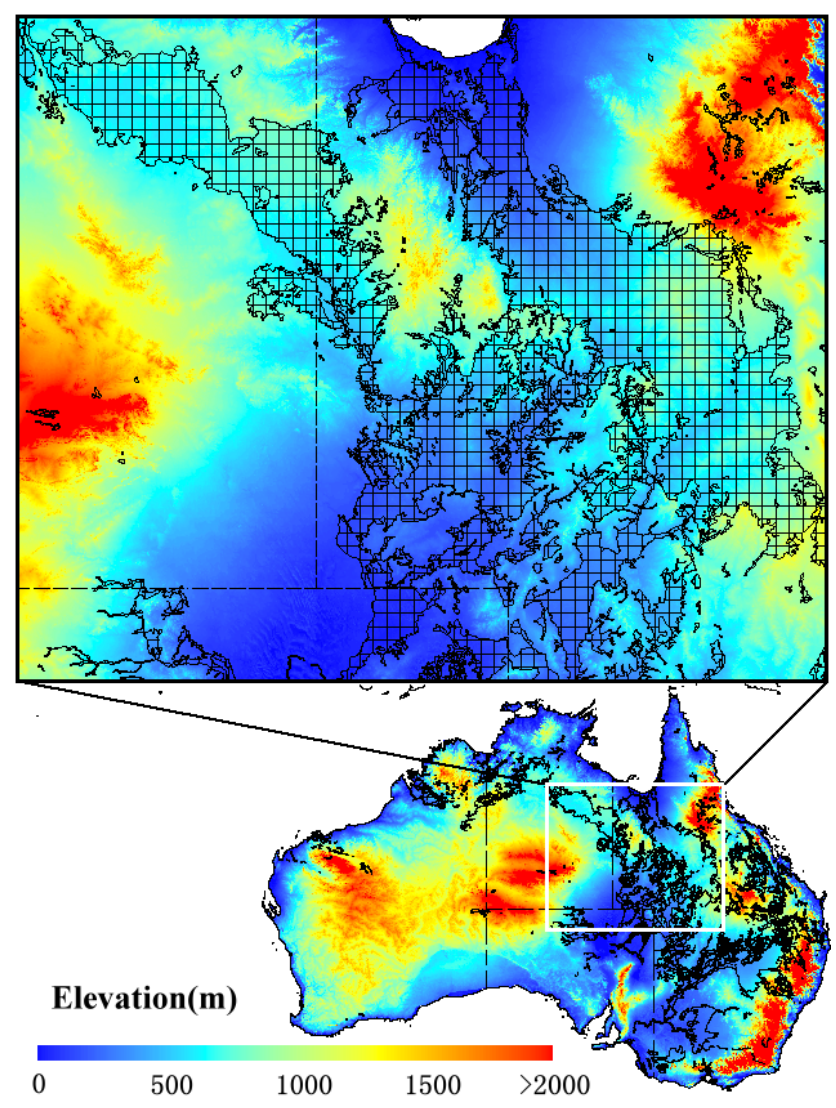

Fig. 4. Elevation map of vertisol regions over mainland Australia.

during dry periods can not be attributed to land management. The landscape across this region and non-clay soils in their vicinity is reasonably flat (Fig. 4) and therefore topography appears to play no significant role in AMSR-E soil moisture retrievals either.

Both NDVI and AMSR-E vegetation optical depth demonstrate low vegetation density over vertisols and surrounding non-clay soils during January and October 2004, typical of the vegetation coverage in this region (Fig. 5). During the dry October 2004, the NDVI over the Mitchell Grass Downs is clearly lower than surrounding areas, which might be attributed to the vegetation types. While the surrounding non-clay areas are mainly covered by perennial hummock grasses, woodlands and shrublands, the Mitchell Grass Downs are dominated by relatively short Mitchell grasses with little top cover (Cofinas and Creighton, 2001). The cattle grazing activities over the Mitchell Grass Downs may further exacerbate the difference.

Temporally, AMSR-E $\tau$ and NDVI show very similar vegetation seasonality (Fig. 6). Over region A, the fluctuations of both products are highly correlated. Over region B, slight differences can be observed between August and November. While NDVI has a decreasing tendency, AMSR-E $\tau$ slightly increases or stays constant. Overall, low vegetation density 
(a) AMSR-E Vegetation optical depth (January 2004)

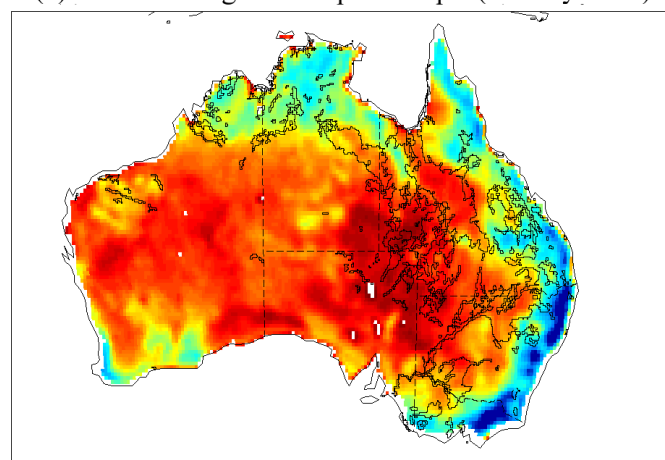

(c) AMSR-E Vegetation optical depth(October 2004)

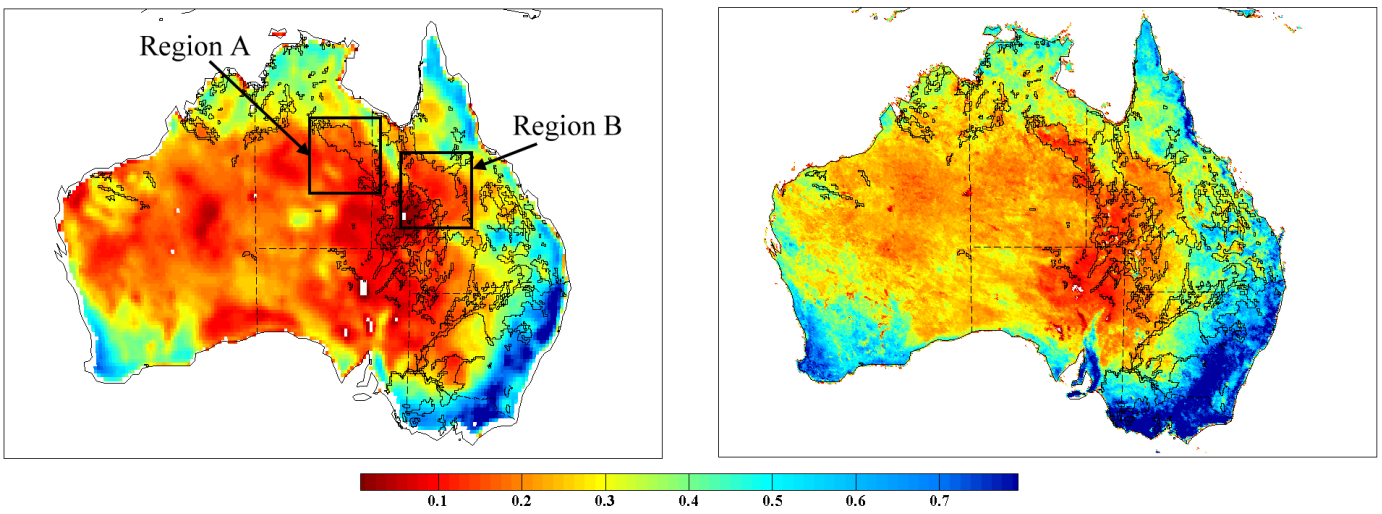

(b) NDVI (January 2004)

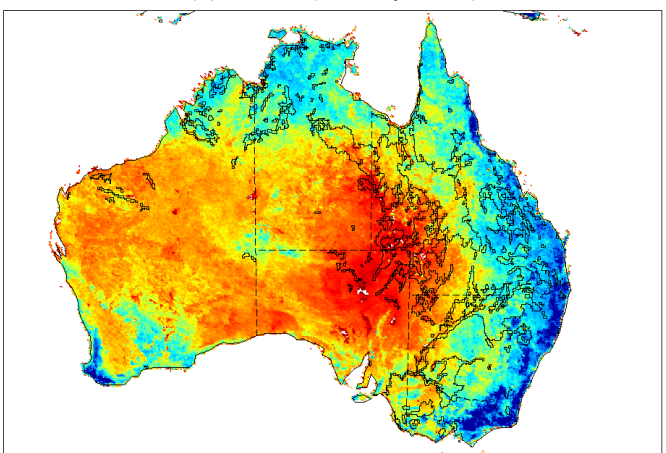

(d) NDVI (October 2004) 
(a) Region $\mathrm{A}$

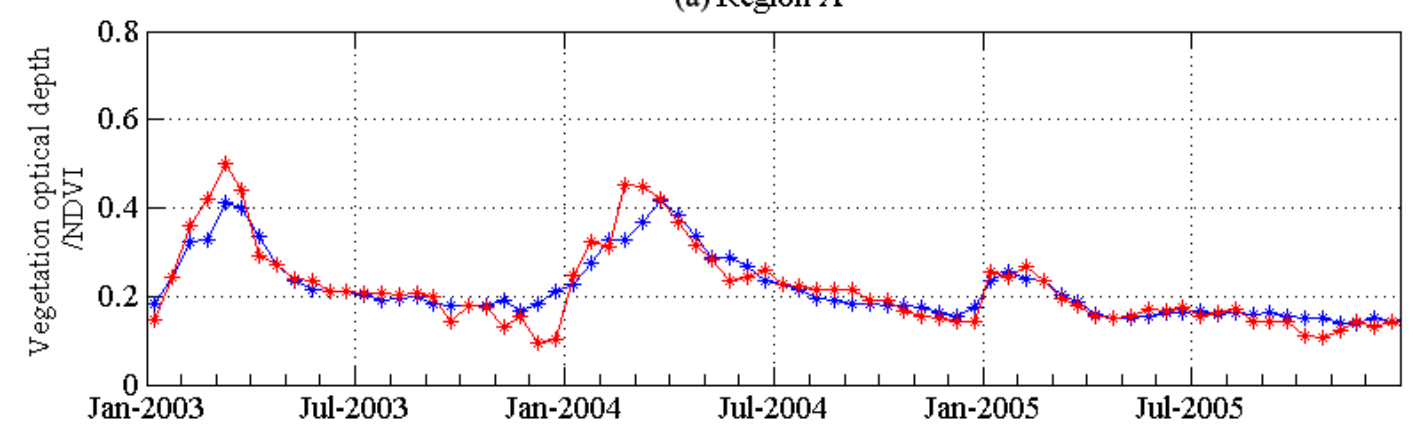

(b) Region B

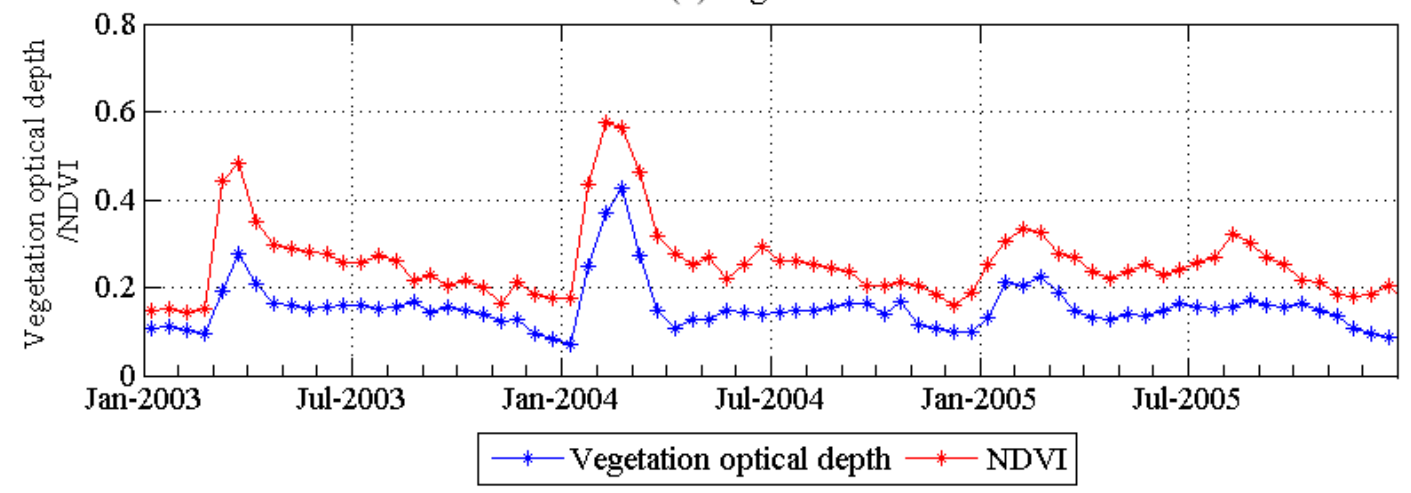

Fig. 6. Time series of averaged AMSR-E $\tau$ and GIMMS NDVI of vertisol areas within regions A and B (shown in Fig. 5c). The AMSR-E $\tau$ is resampled to 15-day average for comparison with NDVI. It should be noted that although both products share the same y-axis, they have different physical interpretations (see Sect. 2.3).

\subsubsection{Soil porosity and surface roughness}

Both soil porosity and surface roughness are assumed constant in the VUA-NASA algorithm. Figure 10 qualitatively illustrates how neglecting an increase in soil porosity could lead to an underestimation of soil moisture. Suppose that under a condition of no cracks, soil porosity of the entire soil column is $0.45 \mathrm{~m}^{3} \mathrm{~m}^{-3}$ and soil moisture is $0.1 \mathrm{~m}^{3} \mathrm{~m}^{-3}$. When cracks are open, the soil porosity of the top soil layer may increase to $0.6 \mathrm{~m}^{3} \mathrm{~m}^{-3}$ (while soil moisture is still assumed to be $0.1 \mathrm{~m}^{3} \mathrm{~m}^{-3}$ ). The increase in soil porosity increases the proportion of air and decreases the fraction of soil (including soil water and solid soil material) within a unit volume. The dielectric constant of air is much smaller than solid soil and water, thus increasing soil porosity will reduce the mixture dielectric constant for the same soil moisture (Fig. 10b). The soil porosity (0.45) and fraction of clay/sand $(40 \% / 31 \%)$ are taken from FAO and represent typical values for vertisols over mainland Australia. Surface temperature $\left(T_{\mathrm{s}}: 300 \mathrm{~K}\right)$ is representative over vertisols in north Australia during October 2004. The Wang-Schmugge model (Wang and Schmugge, 1980) is utilized to link these variables (also including actual soil moisture and soil porosity) to the mixed dielectric constant.
Figure 10c shows that if the increase in soil porosity (i.e., from 0.45 to 0.6 ) is not considered, the retrieved soil moisture will be lower than the actual soil moisture. One might expect that the difference between retrieved and actual soil moisture will be greater when the cracks at the surface are wider. As shown in Fig. 10c, when the actual soil moisture is $0.1 \mathrm{~m}^{3} \mathrm{~m}^{-3}$ and soil porosity of vertisols increases to 0.7 , the retrieved soil moisture is as low as $0.02 \mathrm{~m}^{3} \mathrm{~m}^{-3}$ if ignoring the change in soil porosity. If soil porosity keeps increasing and/or actual soil moisture decreases, the dielectric constant may be lower than that when soil moisture is zero and soil porosity is 0.45 , which will result in "invalid" soil moisture retrievals.

De Jeu et al. (2009) demonstrated that increasing the value of surface roughness in the VUA-NASA algorithm when the soil dries would improve the accuracy of remote sensing soil moisture retrievals. Here we compare the influences of surface roughness and soil porosity on the AMSR-E retrievals: that is, only changing surface roughness or soil porosity while keeping everything else constant. Increasing surface roughness or soil porosity can increase the values of $\theta$ (Fig. 11). The difference is that increasing surface roughness will result in lower $\tau$, while increasing soil porosity will not affect the values of $\tau$. Thus comparing AMSR-E $\tau$ with 
(a) Rainfall (January 2004)

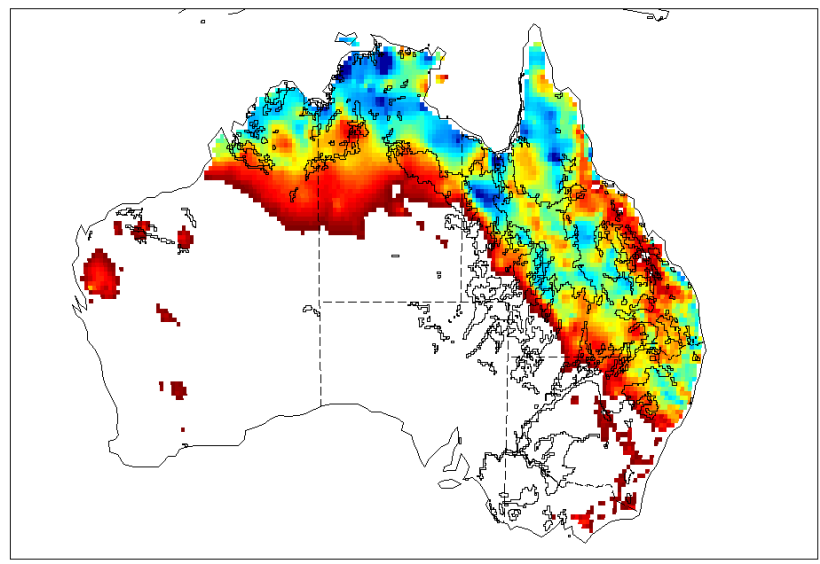

(b) Rainfall (October 2004)

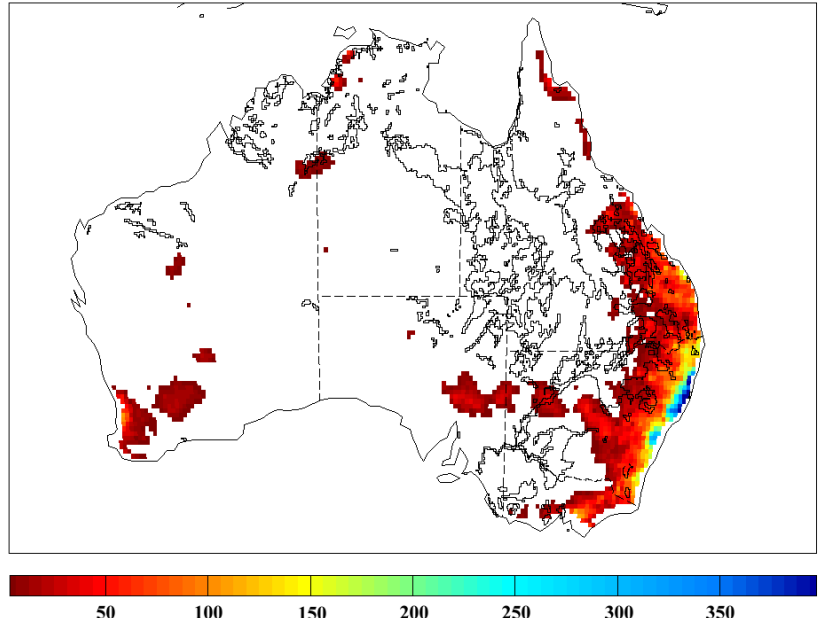

Fig. 7. Monthly total rainfall (mm) for January and October 2004.

other vegetation index (e.g., NDVI) may help determine the more important factor in the underestimation of AMSR-E $\theta$ over vertisols. If AMSR-E $\tau$ highly agree with NDVI (e.g., Fig. 6a), low values of AMSR-E $\theta$ over vertisols may be mainly attributed to soil porosity change. If AMSR-E $\tau$ deviates from the pattern of NDVI (e.g. NDVI decreasing while $\tau$ increasing as shown in Fig. 6b), AMSR-E $\tau$ seems to be overestimated and thus the change in surface roughness may play a crucial role.

In the absence of any in situ measurements over these vertisol regions, we can not perform any quantitative analysis to identify the individual contribution from soil porosity and surface roughness; however it is clear that both factors play a role in the underestimation of $\theta$ when cracks are present. More in situ measurements of soil properties (e.g., soil moisture, soil porosity and fractions of clay and sand) representing different stages of cracking over vertisols need to be collected to better characterize these responses. (a) AMSR-E (January 2004)

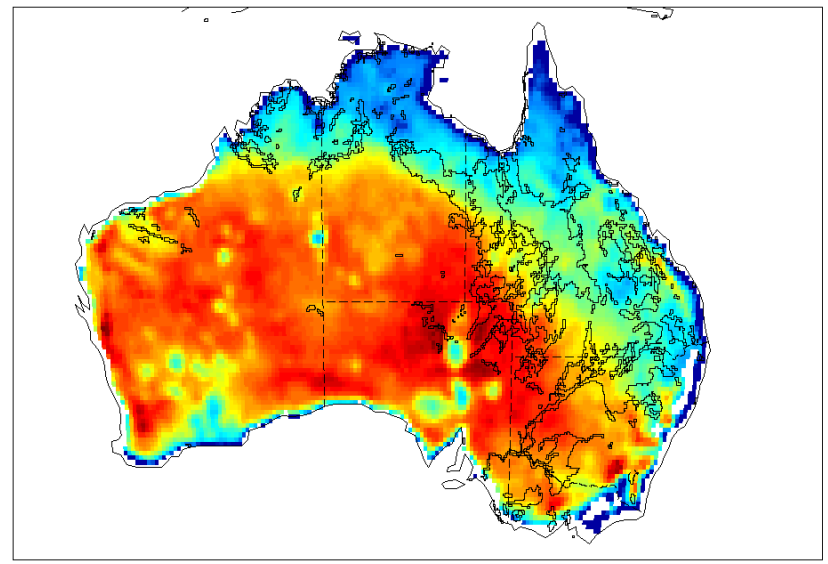

(b) AMSR-E (October 2004)

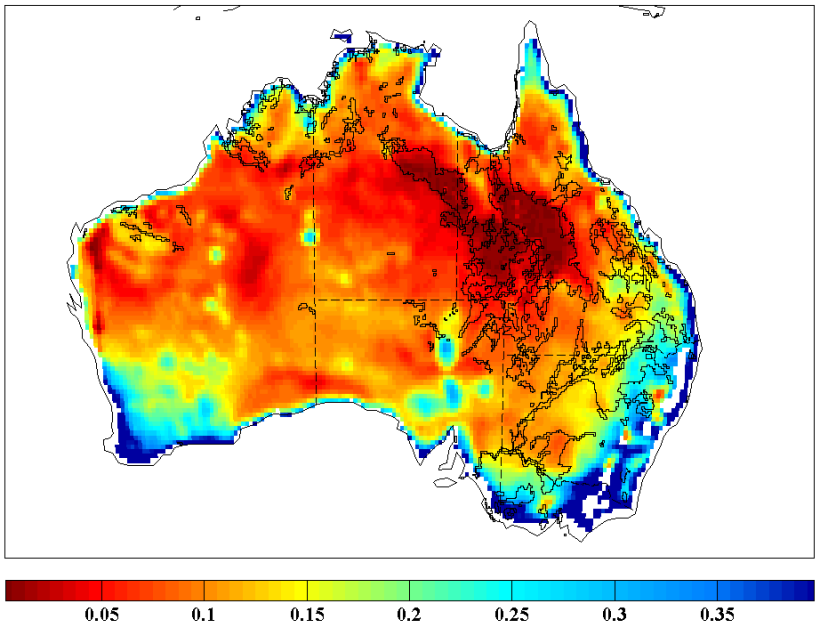

Fig. 8. Monthly averages of AMSR-E surface soil moisture $\left(\mathrm{m}^{3} \mathrm{~m}^{-3}\right)$ for January and October 2004, using uniform soil properties (soil porosity and fractions of sand/clay) in the retrieval algorithm.

\subsection{Effects of soil physical characteristics on CLM}

We now discuss whether CLM reasonably represent the soil moisture over vertisols. As expected, values of CLM $\theta$ over vertisols are higher than surrounding non-clay soils in the dry season (Fig. 2), as the smaller clay particles are able to retain more water molecules. This means that the soil type is reasonably represented in the land surface model. In addition, the vegetation types and topographic conditions represented in the CLM are quite similar as shown in Figs. 4 and 5 with slight differences in spatial resolution (see http://ldas.gsfc.nasa.gov/gldas). The temporal responses of AMSR-E and CLM $\theta$ are rather similar during the wet season (Fig. 3), which means the precipitation is also well represented in the land surface model.

Therefore, the most likely reason for the divergence between AMSR-E and CLM $\theta$ during the dry season (see Fig. 3), from the land surface model perspective, seems to 


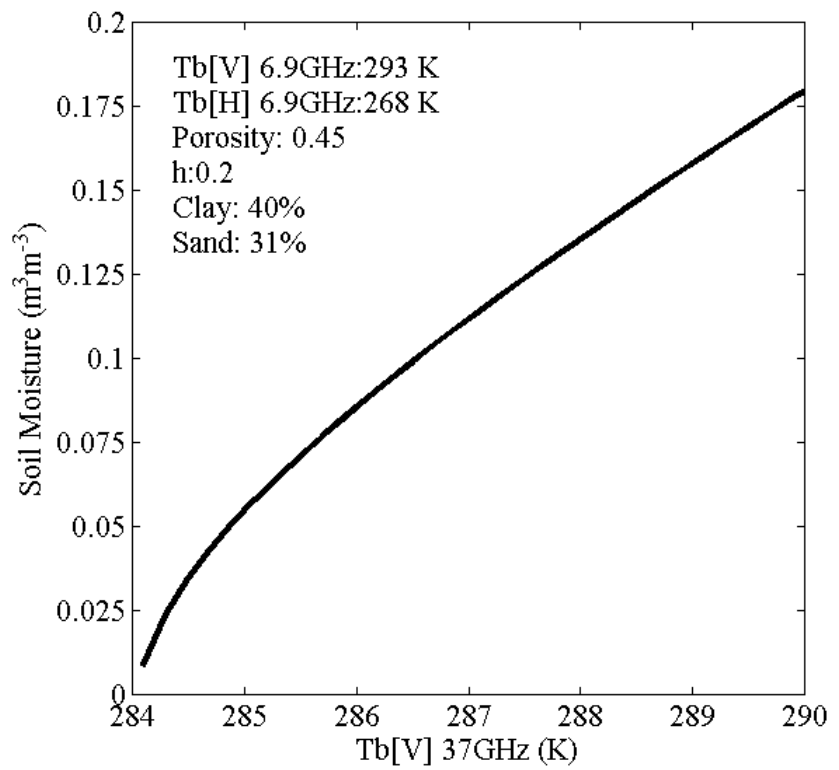

Fig. 9. The impacts of $37 \mathrm{GHz}$ vertical $T_{\mathrm{b}}$ on retrieved soil moisture using the VUA-NASA algorithm. The vertical and horizontal $T_{\mathrm{b}}$ at $6.9 \mathrm{GHz}$ are taken from AMSR-E observations on 1 October 2004 for one grid cell over the vertisols within region A (shown in Fig. 5). Soil porosity and fractions of clay/sand are taken from FAO soil property dataset for the same grid cell.

lie in the lowest CLM $\theta$. In the dry season, the lowest CLM $\theta$ stays at permanent wilting point when $\Psi_{\max }$ is equal to $-1.5 \times 10^{5} \mathrm{~mm}$. From Eqs. (1), (2) and (3) it can be seen that minimum soil moisture is dependent on fractions of clay and sand. Clay soils have greater $\Psi_{\text {sat }}$, higher $\theta_{\text {sat }}$ and higher value of $B$. From Eq. (4), we can calculate that under the same $\Psi$, the $\theta$ of clay soils is higher than non-clay soils. For soils without cracking characteristics, it might be valid that the lowest $\theta$ is reached at the permanent wilting point. However, the field experiment conducted by Chan and Hodgson (1981) over cracking grey clay soils in southeast Australia revealed that once cracks in vertisols are formed, further loss of moisture from soil also occurs as direct evaporation, drying the soil to below the permanent wilting point. The measured $\Psi$ can decrease to $-8.0 \times 10^{5} \mathrm{~mm}$ and even lower. Selim and Kirkham (1970) performed a laboratory experiment and found that cracks could increase the total evaporation by $2.5 \mathrm{~cm}$ over 12 days, $30 \%$ higher than soils without cracks. Without considering cracks, CLM $\theta$ over vertisols during dry periods is therefore likely overestimated, which may partially cause the increasing difference between AMSR-E and CLM $\theta$ during dry seasons (Fig. 3). Furthermore, the underestimated evaporation might lead to an overestimation of sensible heat and surface temperature over vertisols. Evans and McCabe (2010) found that a regional climate models simulated surface temperature over vertisols in summer (when vertisols regularly dry out and crack) were higher than the observed temperature by more than $2 \mathrm{~K}$ - a possible repercussion of the poor representation of the cracking clay soils.
The impacts of soil cracking on the hydrological cycle are not limited to surface soil moisture and evaporation. Austin and Prendergast (1997) conducted a border (also referred to as flood, surface or bay) irrigation experiment over cracked soils in south-east Australia and found that the infiltration through soil cracks represented almost half of the total irrigation. In the Ord River Irrigation Area in north-western Australia, Smith (2008) observed the persistent groundwater rise during the past 10 years, and attributed this to large infiltration losses through cracking clays in the early wet season. Over rain-fed crops on clay soils in central Queensland, the infiltration rate when cracks are open is greater than $25 \mathrm{~mm}$ per hour, while the infiltration rate is only $1-2 \mathrm{~mm}$ per hour when no cracks are present. Outside Australia, Allen et al. (2005) monitored the rainfall, runoff, soil moisture, and groundwater levels over a hydrological year in north-central Texas and found that recharge through the cracks allowed rapid and relatively deep wetting of otherwise impermeable clays. This finding is also supported by Amidu and Dunbar (2007). This may explain why the largest difference between CLM and AMSR-E $\theta$ is observed at the beginning of the rainy season (Fig. 3). At the start of the wet season, the cracks are present and AMSR-E $\theta$ is still underestimated. Without considering open cracks in CLM, the water actually infiltrating into open cracks might be partly considered as surface soil moisture in the simulations, which explains the largest discrepancy between AMSR-E and CLM $\theta$. After several rainfall events, cracks disappear and the AMSR-E and CLM $\theta$ gradually converge.

\section{Conclusions}

AMSR-E retrievals and CLM simulations provide two different approaches to approximating the actual soil moisture. Responses of estimated soil moisture to meteorological conditions correspond well during wet periods. However, neither approach adequately accounts for the behavior of cracking clays under very dry conditions. Since the cracking behavior of clays has impacts on the partitioning of precipitation and irrigation waters into groundwater recharge, soil moisture, surface runoff and evaporation, model outputs from CLM and AMSR-E retrievals should be interpreted with care over these soil conditions.

From the aspect of AMSR-E retrieval, the assumption of constant soil porosity and surface roughness in the retrieval algorithm results in underestimation of soil moisture. How to cope with temporal changes in soil porosity and surface roughness remains a challenge to retrieving soil moisture from passive microwave satellite observations. This study illustrates that the effect of cracking soils is one reason why it is difficult to derive estimates of soil moisture content over the top few $\mathrm{cm}$ of the soil column with good absolute accuracy. Even if we could, the relationship of absolute water content between top layer and greater depth can be weak 
(a)

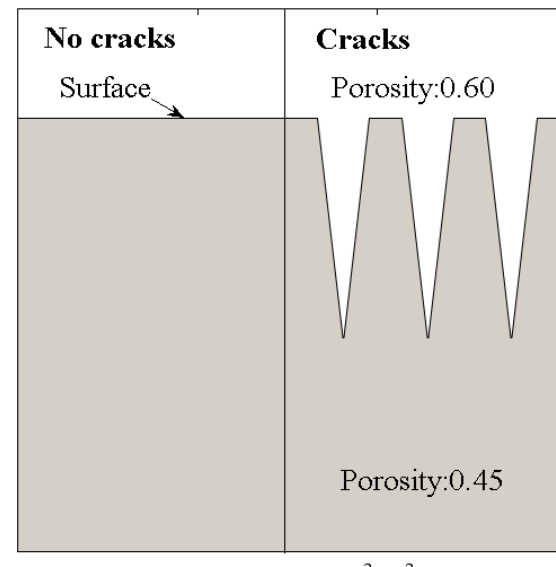

Soil Moisture: $0.1 \mathrm{~m}^{3} \mathrm{~m}^{-3}$ (b)

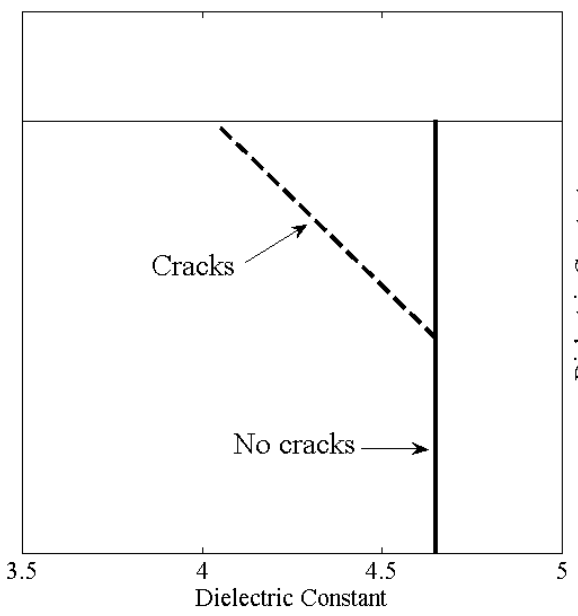

(c)

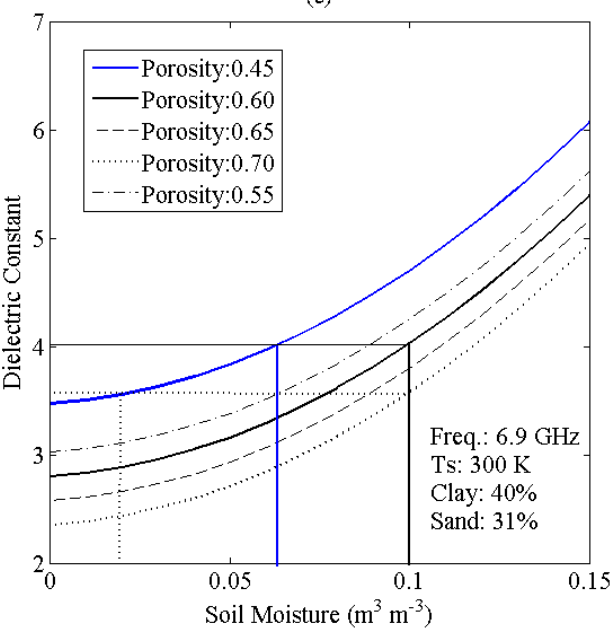

Fig. 10. Simplified illustration of how open cracks increase soil porosity and further lead to an underestimation of soil moisture. With cracks opening, the porosity at the surface will increase. Due to the low dielectric constant of air, the mixed dielectric constant at the surface will decrease. Without considering the increase in porosity, the estimated soil moisture will be lower than the actual.

(a)

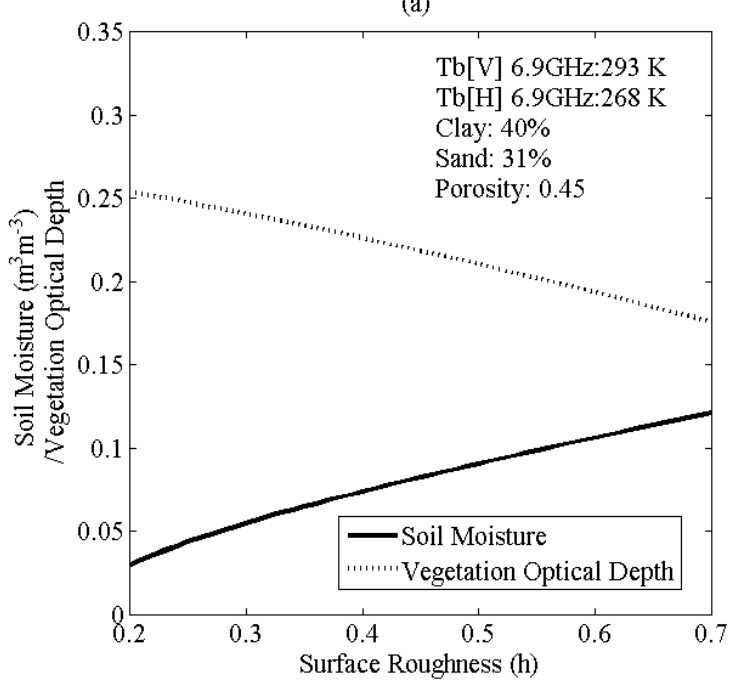

(b)

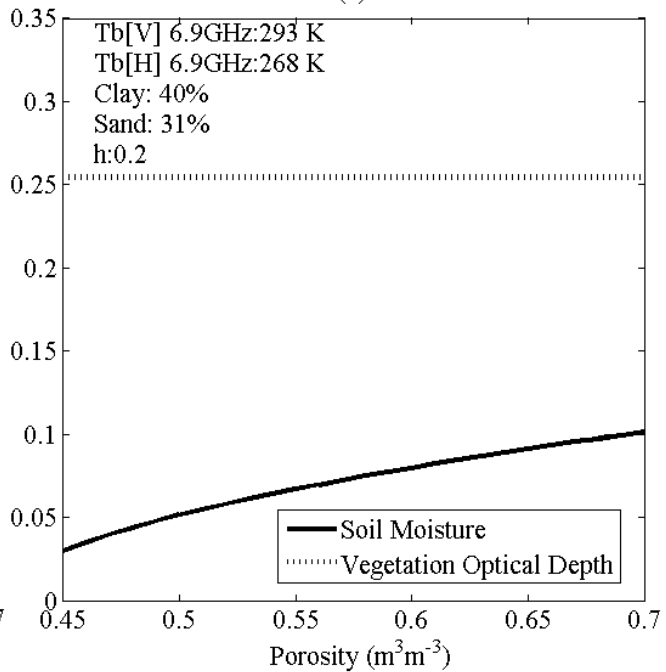

Fig. 11. The impacts of (a) surface roughness $(h)$ and (b) soil porosity on retrieved soil moisture and vegetation optical depth using VUANASA algorithm.

(Manfreda et al., 2007), not just because of soil water movement (e.g. infiltration into open cracks), but also due to vertical changes in structure and bulk density (Van Dam, 2000).

However, this need not be a major obstacle for useful application of satellite passive microwave soil moisture for many purposes. Crow et al. (2009) demonstrate how improvements in satellite-based rainfall estimates can be achieved by utilizing changes in satellite-based soil moisture retrievals over the contiguous United States. Reichle and Koster (2004) used the cumulative distribution functions matching technique before assimilating $\theta$ into GLDAS, illustrating that absolute accuracy is not necessarily required.
Liu et al. (2009) demonstrated that a merged satellite-based soil moisture product from several instruments on different satellites could capture the actual long term changes in surface water availability despite low absolute accuracy of original products. McCabe et al. (2008) also describe using soil moisture retrievals as an independent evaluation variable for other remote sensing retrievals and land surface model output. Efforts to utilize the spatial pattern intrinsic in satellite based retrievals also provide a novel means of utilizing the information rich data. 
From a land surface modeling perspective, if the influence of cracking soils are not considered, the accurate partitioning of precipitation into soil moisture, evaporation, infiltration and surface runoff is likely to be affected, suggesting that caution be used in interpreting these model outputs.

Despite uncertainties related to cracking clays, useful information can still be obtained from comparisons between AMSR-E and CLM soil moisture. The differences between CLM and AMSR-E soil moisture might indicate the periods of crack formation, expanding and resealing. Developing a dynamic module of "cracking clays" and incorporating this into land surface and hydrological models may improve the estimates of hydrological cycle and energy fluxes.

The influence of cracking vertisols on AMSR-E retrieved soil moisture illustrated in this paper remains an open issue to address in both current and future soil moisture missions, such as the Soil Moisture and Ocean Salinity (SMOS) and Soil Moisture Active/Passive (SMAP) sensors. To achieve the stated aim of providing volumetric soil moisture with the accuracy of $0.04 \mathrm{~m}^{3} \mathrm{~m}^{-3}$ or better (Kerr et al., 2000; SMAP Mission, 2007), attention to such issues is required.

Acknowledgements. This work was supported by the University International Postgraduate Award (UIPA) from University of New South Wales and a top-up scholarship from the CSIRO Water for a Healthy Country Flagship Program, along with the Australian Research Council's Discovery Projects funding scheme (project number DP0772665). We are also grateful to Wade Crow, Rogier van der Velde and another two anonymous referees for their valuable suggestions on an earlier manuscript.

Edited by: Z. Su

\section{References}

Allen, P. M., Harmel, R. D., Arnold, J., Plant, B., Yelderman, J., and King, K.: Field data and flow system response in clay (vertisol) shale terrain, north central Texas, USA, Hydrol. Process., 19, 2719-2736, doi:10.1002/hyp.5782, 2005.

Amidu, S. A. and Dunbar, J. A.: Geoelectric studies of seasonal wetting and drying of a texasvertisol, Vadose Zone J., 6, 511523, doi:10.2136/vzj2007.0005, 2007.

Austin, N. R. and Prendergast, J. B.: Use of kinematic wave theory to model irrigation on cracking soil, Irrigation Sci., 18, 1-10, 1997.

Australian Natural Resources Atlas (ANRA), http://www.anra. gov.au/topics/rangelands/overview/nt/ibra-mgd.html, access: 27 May 2010, 2001.

Bonan, G. B., Oleson, K. W., Vertenstein, M., Levis, S., Zeng, X., Dai, Y., Dickinson, R. E., and Yang, Z.: The land surface climatology of the community land model coupled to the NCAR community climate model, J. Climate, 15, 3123-3149, 2002.

Chan, K. Y. and Hodgson, A. S.: Moisture regimes of a cracking clay soil under furrow irrigated cotton, Australian Journal of Experimental Agriculture and Animal Husbandry, 21, 538-542, 1981.
Choi, M., Jacobs, J. M., and Bosch, D. D.: Remote sensing observatory validation of surface soil moisture using Advanced Microwave Scanning Radiometer E, Common Land Model, and ground based data: Case study in SMEX03 Little River Region, Georgia, U.S., Water Resour. Res., 44, W08421, doi:10.1029/2006WR005578, 2008.

Cofinas, M. and Creighton, C.: National Land and Water Resources Audit Australian Native Vegetation Assessment, http: //www.nlwra.gov.au/products/pr020284, access: 27 May 2010, 2001.

Cornelis, W. M., Corluy, J., Medina, H., Diaz, J., Hartmann, R., van Meirvenne, M., and Ruiz, M. E.: Measuring and modelling the soil shrinkage characteristic curve, Geoderma, 137, 179-191, doi:10.1016/j.geoderma.2006.08.022, 2006.

Crow, W. T., Huffman, G. J., Bindlish, R., and Jackson, T. J.: Improving satellite-based rainfall accumulation estimates using spaceborne surface soil moisture retrievals, J. Hydrometeorol. 10, 199-212, doi:10.1175/2008JHM986.1, 2009.

Dai, Y., Zeng, X., Dickinson, R. E., Baker, I., Bonan, G. B., Bosilovich, M. G., Denning, A. S., Dirmeyer, P. A., Houser, P. R., Niu, G., Oleson, K. W., Schlosser, C. A., and Yang, Z.: The Common Land Model, B. Am. Meteorol. Soc., 84, 1013-1023, 2003.

De Jeu, R. A. M.: Retrieval of Land Surface Parameters Using Passive Microwave Observations, VrijeUniversiteit Amsterdam, Amsterdam, 120 pp., 2003.

De Jeu, R. A. M., Holmes, T. R. H., Panciera, R., and Walker, J. P.: Parameterization of the Land Parameter Retrieval Model for LBand Observations Using the NAFE'05 Data Set, IEEE Geosci. Remote S., 6, 630-634, doi:10.1109/LGRS.2009.2019607, 2009.

Draper, C. S., Walker, J. P., Steinle, P. J., de Jeu, R. A. M., and Holmes, T. R. H.: An evaluation of AMSR-E derived soil moisture over Australia, Remote Sens. Environ., 113, 703-710, doi:10.1016/j.rse.2008.11.011, 2009.

Evans, J. P. and McCabe, M. F.: Regional climate simulation over Australia's Murray-Darling Basin: a multi-temporal assessment, J. Geophys. Res., doi:10.1029/2010JD013816, in press, 2010.

Gao, H., Wood, E. F., Jackson, T. J., Drusch, M., and Bindlish, R.: Using TRMM/TMI to retrieve surface soil moisture over the southern United States from 1998 to 2002, J. Hydrometeorol., 7, 23-38, 2006.

Holmes, T. R. H., de Jeu, R. A. M., Owe, M., and Dolman, A. J.: Land surface temperature from $\mathrm{Ka}$ band $(37 \mathrm{GHz})$ passive microwave observations, J. Geophys. Res., 114, D04113, doi:10.1029/2008JD010257, 2009.

Isbell, R. F.: The Australian Soil Classification. Revised Edition, CSIRO Publishing, Melbourne, 2002.

Jackson, T. J. and Schmugge, T. J.: Surface Soil-Moisture Measurement with Microwave Radiometry, ActaAstronaut., 35, 477-482, 1995.

Kerr, Y., Font, J., Waldteufel, P., and Berger, M.: The Second of ESA's Opportunity Missions: The Soil Moisture and Ocean Salinity Mission - SMOS, Earth Observation Quarterly, 66, 1825,2000

Kuria, D. N., Koike, T., Lu, H., Tsutsui, H., and Graf, T.: FieldSupported Verification and Improvement of a Passive Microwave Surface Emission Model for Rough, Bare, and Wet Soil Surfaces by Incorporating Shadowing Effects, IEEE T. Geosci. Remote, 
45, 1207-1216, doi:10.1109/TGRS.2007.894552, 2007.

Liu, Y. Y., van Dijk, A. I. J. M., de Jeu, R. A. M., and Holmes, T. R. H.: An analysis of spatiotemporal variations of soil and vegetation moisture from a 29-year satellite-derived data set over mainland Australia, Water Resour. Res., 45, W07405, doi:10.1029/2008WR007187, 2009.

Manfreda, S., McCabe, M. F., Fiorentino, M., Rodriguez-Iturbe, I., and Wood, E. F.: Scaling characteristics of spatial patterns of soil moisture from distributed modeling, Adv. Water Resour., 30, 2145-2150, doi:10.1016/J.Advwatres.2006.07.009, 2007.

McCabe, M. F., Gao, H., and Wood, E. F.: Evaluation of AMSR-EDerived Soil Moisture Retrievals Using Ground-Based and PSR Airborne Data During SMEX02, J. Hydrometeorol., 6, 864-877, doi: 10.1175/JHM463.1, 2005a.

McCabe, M. F., Wood, E. F., and Gao, H.: Initial soil moisture retrievals from AMSR-E: Multiscale comparison using in situ data and rainfall patterns over Iowa, Geophys. Res. Lett., 32, L06403, doi:10.1029/2004GL021222, 2005b.

McCabe, M. F., Wood, E. F., Wojcik, R., Pan, M., Sheffield, J., Gao, $\mathrm{H}$., and $\mathrm{Su}, \mathrm{H}$.: Hydrological consistency using multi-sensor remote sensing data for water and energy cycle studies, Remote Sens. Environ., 112, 430-444, doi:10.1016/j.rse.2007.03.027, 2008.

Njoku, E. G. and Entekhabi, D.: Passive microwave remote sensing of soil moisture, J. Hydrol., 184, 101-129, 1996.

Njoku, E. G., Ashcroft, P., Chan, T. K., and Li, L.: Global survey and statistics of radio-frequency interference in AMSRE land observations, IEEE T. Geosci. Remote, 43, 938-947, doi:10.1109/TGRS.2004.837507, 2005.

Oleson, K. W., Dai, Y., Bonan, G., Bosilovich, M., Dickinson, R., Dirmeyer, P., Hoffman, F., House, P., Levis, S., Niu, G., Thornton, P., Vertenstein, M., Yang, Z., and Zeng, X.: Technical Description of the Community Land Model (CLM), Terrestrial Sciences Section, Climate and Global Dynamics Division, National Center for Atmosphere Research, Boulder, Colorado, 2004.

Owe, M., de Jeu, R., and Holmes, T.: Multisensor historical climatology of satellite-derived global land surface moisture, J. Geophys. Res., 113, F01002, doi:10.1029/2007JF000769, 2008.

Reichle, R. H. and Koster, R. D.: Bias reduction in short records of satellite soil moisture, Geophys. Res. Lett., 31, L19501, doi:10.1029/2004GL020938, 2004.

Rodell, M., Houser, P. R., Jambor, U., Gottschalck, J., Mitchell, K., Meng, C.-J., Arsenault, K., Cosgrove, B., Radakovich, J., Bosilovich, M. G., Entin, J. K., Walker, J. P., Lohmann, D., and Toll, D.: The Global Land Data Assimilation System, B. Am. Meteorol. Soc., 85, 381-394, 2004.

Rüdiger, C., Calvet, J.-C., Gruhier, C., Holmes, T., de Jeu, R., and Wagner, W.: An Intercomparison of ERS-Scat and AMSR-E Observations, and Soil Moisture Simulations over France, J. Hydrometeorol., 10, 431-447, doi:10.1175/2008JHM997.1, 2009.
Santanello Jr., J. A., Peters-Lidard, C. D., Garcia, M. E., Mocko, D. M., Tischler, M. A., Moran, M. S., and Thoma, D. P.: Using remotely-sensed estimates of soil moisture to infer soil texture and hydraulic properties across a semi-arid watershed, Remote Sens. Environ., 110, 79-97, doi:10.1016/j.rse.2007.02.007, 2007.

Scipal, K., Holmes, T., de Jeu, R., Naeimi, V., and Wagner, W.: A possible solution for the problem of estimating the error structure of global soil moisture data sets, Geophys. Res. Lett., 35, L24403, doi:10.1029/2008GL035599, 2008.

Selim, H. W. and Kirkham, D.: Soil temperature and water content changes during drying as influenced by cracks: a laboratory experiment, Soil Sci. Soc. Am. J., 34, 565-569, 1970.

Smith, A. J.: Rainfall and irrigation controls on groundwater rise and salinity risk in the Ord River Irrigation Area, northern Australia, Hydrogeol. J., 16, 1159-1175, 2008.

Soil Moisture Active Passive (SMAP) Mission, NASA Workshop Report: http://science.nasa.gov/media/medialibrary/2010/03/31/ Volz1_SMAP_11-20-07.pdf, access: 27 May 2010, 2007.

Tucker, C. J., Pinzon, J. E., Brown, M. E., Slayback, D. A., Pak, E. W., Mahoney, R., Vermote, E. F., and El Saleous, N.: An Extended AVHRR 8-km NDVI Data Set Compatible with MODIS and SPOT Vegetation NDVI Data, Int. J. Remote Sens., 26, 4485-4498, 2005.

Van Dam, J. C.: Simulation of field-scale water flow and bromide transport in a cracked clay soil, Hydrol. Processes, 14, 11011117, 2000.

Vischel, T., Pegram, G. G. S., Sinclair, S., Wagner, W., and Bartsch, A.: Comparison of soil moisture fields estimated by catchment modelling and remote sensing: a case study in South Africa, Hydrol. Earth Syst. Sci., 12, 751-767, doi:10.5194/hess-12-7512008, 2008.

Wagner, W., Lemoine, G., and Rott, H.: A method for estimating soil moisture from ERS scatterometer and soil data, Remote Sens. Environ., 70, 191-207, 1999.

Wagner, W., Scipal, K., Pathe, C., Gerten, D., Lucht, W., and Rudolf, B.: Evaluation of the agreement between the first global remotely sensed soil moisture data with model and precipitation data, J. Geophys. Res., 108, 4611, doi:10.1029/2003jd003663, 2003.

Wang, J. R. and Schmugge, T. J: An Empirical-Model for the Complex Dielectric Permittivity of Soils as a Function of WaterContent, IEEE T. Geosci. Remote, 18, 288-295, 1980.

Wen, J., Su, Z., and Ma, Y.: Determination of land surface temperature and soil moisture from Tropical Rainfall Measuring Mission/Microwave Imager remote sensing data, J. Geophys. Res., 108, 4038, doi:10.1029/2002JD002176, 2003. 